\title{
SUPPORT FOR SMALL RENEWABLE ENERGY SOURCES IN SLOVAKIA
}

\author{
doc. Ing. J ankovichová Eva, Ph.D.
}

\begin{abstract}
Electrical energy and demand is constantly increasing disproportionately. Therefore, taken at Community level long-term programs such as the Europe 2020 strategy, which is primarily focused on the energy sector. Its priorities include reducing greenhouse gas emissions, increase energy efficiency through the development and introduction of innovative technologies and increasing the share of renewable energy sources (RES) at Community level. The issue of implementation of energy from renewable sources in addition to the existing EU environmental strategies key area where attention is focused policy. Therefore, we can expect a significant inflow of funds into the development of these strategic concepts. Improving the energy efficiency is one of the key strategic approaches, contributing to the achievement of greenhouse gas emissions in Community.[1]
\end{abstract}

Key words: small renewable energy sources, energy efficiency, environmental strategies

\section{INTRODUCTION}

Europe committed itself to reduce its GHG (greenhouse gas) emissions by $80-95 \%$ by 2050 and in the shorter term, by 2020 , to reduce GHG by $20 \%$, increase the share of renewable to $20 \%$, and save $20 \%$ energy. The latter is the weakest of the three objectives. Accountability is unclear and monitoring progress mainly indirect and based on estimating policy impacts.

The concept of development of electricity from small renewable energy sources in the Slovak Republic focuses on the analysis tools to support the development of small sources to households. In 2012, the Act on Energy no. 251/2012, as defined, small source to produce electricity to power up to $10 \mathrm{~kW}$ and have been partly eliminate the administrative burden. Institute small source has been introduced especially taking into account the specificities of variable resources, such as photovoltaic and wind. The introduction of small sources continues to hamper the complex permitting process is also relatively very demanding administration source operation. It is therefore necessary to introduce changes to the relevant legislation through simple notification procedure consisting of a single manufacturer's obligation to provide information without further reporting. The proposed legislative modifications are without prejudice to the heat economy.[2]

\section{$1.1 \quad$ Supported devices}

Within the framework of the national project Green households will be supported installation of five of equipment types for renewable energy in households. Household can get support only one device of each type. Family houses are eligible applicants in all five types of facilities (photovoltaic panels, solar collectors, heat pumps, biomass boilers, wind turbines) may thus request the support of several species. Residential buildings could be supported only on solar panels and biomass boilers.

The rules support the installation of small equipment for use RES are defined in the document General conditions to promote renewable energy in the household. For supported equipment the specific requirements apply, which shows when the household is entitled to support for equipment use.[3] 


\subsection{Green households}

In the project Green households:

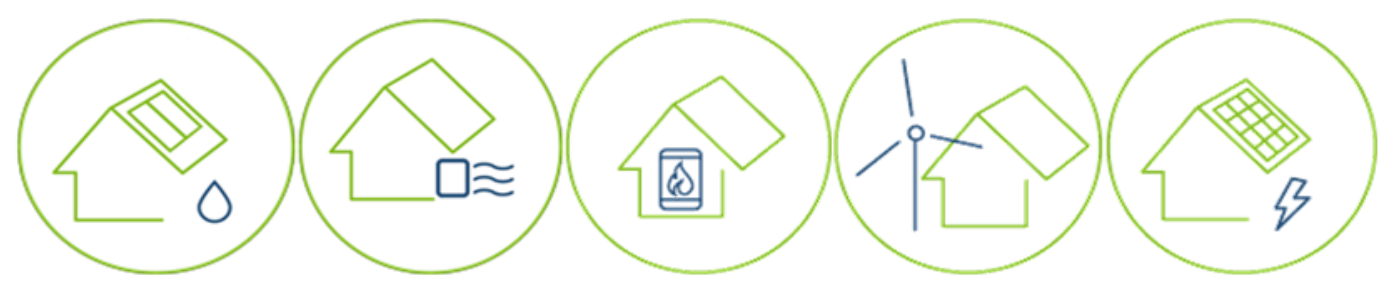

- Residential customers will be able to obtain the contribution of small photovoltaic panels with an output of $10 \mathrm{~kW}$, allowing them to transform solar energy into electricity. As the excess electricity they cannot consume household is supplied to the distribution system free of charge, it is important that the performance of devices designed to produce electricity consumed most households, either immediately at the time of manufacture or by storing electricity in batteries.

- It will be possible to obtain the support for the installation of solar thermal collectors, which are used for hot water and central heating. Priority will be given installation of collectors with an average area of about $5 \mathrm{~m}^{2}$, which represents a sufficient installed thermal capacity of the hot water for normal household family house.

- It will be possible to obtain the support for the installation of heat pumps that will be used primarily for heating. A heat pump device using the heat from the outside. It is particularly suited for low temperature heating systems, such as e.g. floor, wall or ceiling heating in homes with good thermal insulation. The efficient use of renewable energy heat pumps reduce the operating costs for heating and hot water.

- It will be possible to obtain the support for the installation of biomass boilers to cover the needs of heat and domestic hot water. Support refers to boilers burning pellets, briquettes, wood chips and boilers for the gasification of wood logs.

- May comply with the Operational Programme Environmental quality also supported the installation of small wind turbines designed to generate electricity. Actual use of these facilities in Slovakia, but currently prevent multiple obstacles. Because of the need to adjust the laws of general application, it is possible that at the beginning of the project will not be able to issue orders for the installation of wind turbines.[4]

\subsection{0 steps to promote}

There is a national project Green household only in the preparatory phase, households still cannot apply for vouchers. However, they can already prepare afamiliarize with how Slovak Innovation and Energy Agency (SIEA) is planning to provide support.

1. Familiarize yourself with the support conditions

2. Check how renewable energy sources is suitable for your household

3. Choose a contractor and equipment

4. Enclose the contract with the contractor

5. Ask for the issue of vouchers

6. SIEA will send you a contract with voucher 
7. The Contractor will implement installation

8. Hand over all necessary documents to the contractor

9. The Contractor asks for reimbursement voucher

10. SIEA verify the correctness of expenditure actually determine the amount of eligible expenses and reimburse voucher to the contractor[5]

\section{ENERGY EFFICIENCY}

\subsection{Financial Income of Producer from Small Source}

Internal consumption of electricity produced resulting in financial savings for the manufacturer has not taken electricity from the system at an average rate $302.40 € /$ year (see Table 1). The condition is that the household will remain classified as a consumer of electricity in the home and not as an entrepreneur in the energy sector.

\begin{tabular}{|c|c|c|}
\hline One producer & 1 year & $\begin{array}{c}\text { 7 years } \\
\mathbf{( 2 0 1 4 - 2 0 2 0})\end{array}$ \\
\hline Electricity Production $(\mathrm{kWh})$ & 2,000 & 14,000 \\
\hline Self-consumption $80 \%(\mathrm{kWh})$ & 1,600 & 11,200 \\
\hline $\begin{array}{c}\text { Financial saving of producer } \\
\text { (euro) }\end{array}$ & 302.40 & $2,116.80$ \\
\hline
\end{tabular}

Tab. 1 Quantification of the Model Savings an Electricity Producer from a Small Source

\begin{tabular}{|c|c|c|c|c|c|}
\hline Year & $\begin{array}{l}\text { Number of } \\
\text { installations } \\
\text { cumulative }\end{array}$ & $\begin{array}{c}\text { Increase in } \\
\text { earnings for the } \\
\text { saved energy for } \\
\text { one household } \\
\text { (euro) }\end{array}$ & $\begin{array}{c}\text { Average } \\
\text { population of } \\
\text { households }\end{array}$ & $\begin{array}{l}\text { Annual growth of } \\
\text { income per } \\
\text { household } \\
\text { member } \\
\text { (euro) }\end{array}$ & $\begin{array}{c}\text { Number of } \\
\text { people with } \\
\text { increase income } \\
\text { about } 100.80 \\
\text { euro/year }\end{array}$ \\
\hline 2014 & 3,300 & \multirow{7}{*}{302.40} & \multirow{7}{*}{3} & \multirow{7}{*}{100.80} & 9,900 \\
\hline 2015 & 10,000 & & & & 30,000 \\
\hline 2016 & 16,600 & & & & 49,800 \\
\hline 2017 & 26,600 & & & & 79,800 \\
\hline 2018 & 40,000 & & & & 120,000 \\
\hline 2019 & 53,300 & & & & 159,900 \\
\hline 2020 & 67,600 & & & & 202,800 \\
\hline
\end{tabular}

Tab. 2 Calculation Model of Savings Payments for Households Electricity

The median number of residents in one household is three people (Statistical Office SR). The increase in annual income would in monetary terms amounted to 100.80 euro per household member. In 2020, it may be in Slovakia 202,800 citizens with the increase of income 100 per year for saved energy. 
The concept of the electricity development from small renewable energy in Slovakia in the first stage brings a coherent approach to legislative and financial support for the development of small sources of electricity and heat, which is intended to cover his own household consumption, without compromising the stability of the distribution system and the effect of financial savings for operators of small sources and the distribution companies. At this stage, will be considered as suitable sources for households, photovoltaic panels and small wind turbines, photo thermal collectors, heat pumps and biomass boilers for heating, the legislative instruments are designed in particular to facilitate connecting electricity sources, as heat sources are not legally restricted and their installation is easily possible in the current settings system.[2]

\section{RENEWABLE ENERGY IN THE EU 28}

Renewable energy sources cover solar thermal and photovoltaic energy, hydro (including tide, wave and ocean energy), wind, geothermal energy and biomass (including biological waste and liquid biofuels). Wind power is among one of the most important renewable energy sources, which is available to a wider population and compared to the solar system brings even more advantages.

Renewable energy sources cover solar thermal and photovoltaic energy, hydro (including tide, wave and ocean energy), wind, geothermal energy and biomass (including biological waste and liquid biofuels). Wind power is among one of the most important renewable energy sources, which is available to a wider population and compared to the solar system brings even more advantages. Compared with solar system wind system can be more consistent and reliable sources of energy in the home. Wind energy is much less dependent on weather conditions and can operate constantly, when the wind blows a little bit.

In 2012, energy from renewable sources was estimated to have contributed $14.1 \%$ of gross final energy consumption in the EU28, compared with $8.3 \%$ in 2004 , the first year for which this data is available. The share of renewable in gross final energy consumption is one of the headline indicators of the Europe 2020 strategy.[6] The target to be reached by 2020 for the EU28 is a share of $20 \%$ renewable energy use in gross final energy consumption. The national targets.[7] take into account the Member States' different starting points, renewable energy potential and economic performance.

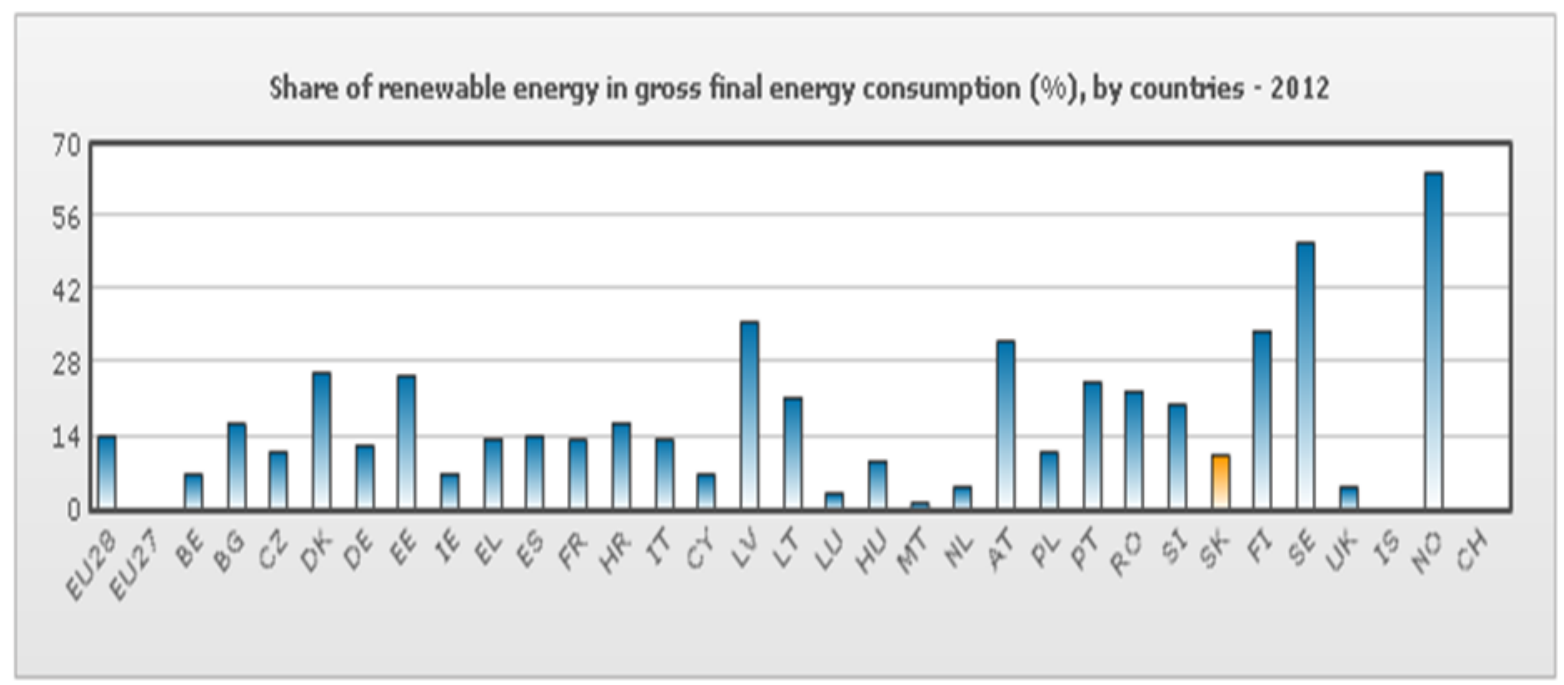

Data for 2010 for MT, IS, CH, ME, MK, TR, US, JP not available. Data source: Eurostat

Fig. 1 Share of renewable energy in gross final energy consumption (\%) 
National energy efficiency ambitions close to cost-effective potentials but overall too low. Most Member States outline energy efficiency ambitions in their NREAPs below cost effective end use saving potentials as predicted by the Energy Savings 2020 report. In consequence Europe's 20\% saving target would be missed.[8]

\section{BARRIERS TO RENEWABLE ENERGY TECHNOLOGIES ADOPTION}

Rapidly increasing energy demand and growing concern about economic and environmental consequences call for renewable/sustainable energy technologies. Renewable/sustainable energy technologies have faced a number of constraints that have affected their rate of adoption. Twentyeight barriers have been identified from an extensive literature review. These identified barriers have been categorized into seven dimensions of barriers, i.e. Economical \& Financial; Market; Awareness \& Information; Technical; Ecological and Geographical; Cultural \& Behavioral; and Political \& Government Issues.

This understanding may be helpful in framing the policies and strategies towards adoption of renewable/sustainable energy technologies.[9]

\section{CONCLUSION}

National target of Slovakia is $14 \%$ of total energy consumption from renewable sources (in the year 2012 it was 10.1\%). Slovakia could improve its competitiveness by reforming its energy sector and by increasing energy efficiency. Slovakia is very energy intensive, with a high share of industry in the economy. At the same time, small and medium sized industrial customers pay rather high electricity prices (Renewable energy in the EU28, 2014).[10]

Slovak government wants to year 2020 to promote renewable energy sources to power up to $10 \mathrm{~kW}$. Support will be for the solar plant and collectors, wind turbines, biomass boilers and heat pumps. Subsidies should be designed not only for family houses but also for the owners' of residential buildings. They should cover about a quarter of the acquisition cost. It may be obtained by those who have undertaken to produce green energy for at least three years. Candidates, who wish to operate their own green energy source, themselves pay roughly three quarters of the rest they remitted in the form of subsidy. The government is prepared to 115 million euro, one hundred million from EU funds. The "Support for Small Renewable Energy" will start next year and should end in 2020.[11]

Following the energy policy of the Slovak Republic and the European Union in Slovakia implemented several measures to increase the share of renewable energy sources (RES) for the production of electricity, heat and biofuels for transport. Achieving a 14\% share of renewables in gross electricity consumption in 2020 determines a National action plan for renewable energy, approved by Government Resolution no. 677 dated 06/10/2010. State of the internal electricity market and achieved share of electricity from renewables in the energy mix requires correction in promoting a gradual rundown of some forms of support.[12] 


\section{Literature}

[1] Energy Efficiency. [online] published 20.03.2014 [cit. 05.07.2014]. Available at: http://www.go-eco.sk/ENERGETICKA-EFEKTIVNOST

[2] Concept of the Eletricity Production Development from Small Renewable Energy Sources in the Slovak Republic, Phase I. [online] published 06.2013 [cit. 29.10.2014]. Available at: http://www.rokovania.sk/File.aspx/ViewDocumentHtml/Mater-Dokum156787?prefixFile=m_

[3] Green Household. [online] published 09.2015 [cit. 13.10.2015]. Available at: http://zelenadomacnostiam.sk/sk/zariadenia/podporovane-zariadenia/

[4] Green Household. [online] published 09.2015 [cit. 13.10.2015]. Available at: http://zelenadomacnostiam.sk/sk/domacnosti/podmienky-podpory/

[5] Green Household. [online] published 09.2015 [cit. 20.10.2015]. Available at: http://zelenadomacnostiam.sk/sk/domacnosti/ako-poziadat-o-poukazku/

[6] Available at: http://ec.europa.eu/europe2020/index_en.htm

[7] Available at: http://ec.europa.eu/energy/renewables/index_en.htm

[8] SCHEUER, S. (2011): Energy Demand in the EU. Comparison of Forecasts and Ambitions. The contributing research paper to Energy Savings 2020. Available at: http://roadmap2050.eu/attachments/files/EnergydemandintheEU

Acomparisionofforecastsandambitions.pdf

[9] Sunil Lutra-Sanjay Kumar-Dixit Garg-Abid Haleem (2015): Barriers to renewable/sustainable energy technologies adoption: Indian perspective. In: Renewable and Sustainable Energy Reviews, ELSEVIER, Vol. 41, January 2015, pp.762-776. Available at: http://www.sciencedirect.com/science/article/pii/S 1364032114007631

[10] Available at: http://epp.eurostat.ec.europa.eu/cache/ITY_PUBLIC/8-10032014-AP/EN/810032014-AP-EN.PDF

[11] State Support to Home Invasion Solaris. In: Diary SME, 10.02.2014, p. 1, 6

[12] Green Household. [online] published 09.2015 [cit. 12.10.2015]. Available at: vhttp://www.op-kzp.sk/obsah-aktuality/vyzvanie-na-prelozenie-narodneho-projektu-zelenadomacnostiam-opkzp-po4-sc411412-2015-np1/ 